\title{
A Study on Potential for Using New Energy and Renewable Energy Sources in Railways
}

\author{
Xinjun Zhou \\ Railway Science \& Technology Research \& Development Center, China Academy of Railway Sciences Corporation Limited, Beijing, China \\ Email address: \\ bfzxj@163.com

\section{To cite this article:} \\ Xinjun Zhou. A Study on Potential for Using New Energy and Renewable Energy Sources in Railways. International Journal of Energy and \\ Power Engineering. Vol. 8, No. 4, 2019, pp. 45-51. doi: 10.11648/j.ijepe.20190804.13
}

Received: September 26, 2018; Accepted: January 22, 2019; Published: August 19, 2019

\begin{abstract}
Railway is a kind of widely recognized low-carbon means of transport in which new energy and renewable energy sources can be used on a large scale for rail traction. Also, the power and various forms of heat provided by new energy and renewable energy sources can be used massively for non-traction purposes. The share of electrified railways is the main factor determining the utilization of new energy and renewable energy in railways. The total length of electrified railways in China has exceeded $6.5 \times 104 \mathrm{~km}$ and it is the longest worldwide. The share of electrified railways in China is expected to reach or even exceed $70 \%$ by 2020 . Worldwide, electric traction has an enormous room for further development, creating a sound technical platform for a large-scale application of new energy and renewable energy sources. As for non-traction applications, because there are usually a lot of large stations along a railway line, energy use is intensive. This, plus the power needed from equipments along the line, creates conditions for the use of new energy and renewable energy sources. China started to research, develop and utilize the new energy and renewable energy sources in its railways a long time ago and the main energy sources used include solar energy, ground source heat pumps and air source heat pumps. With the use of new energy and renewable energy sources, the railway industry can become a pathfinder to first extensively realize the low-carbon or carbon-free growth among all the industries, and this still requires the further consummation of relevant policies and a strong support from government.
\end{abstract}

Keywords: New Energy, Renewable Energy, Railway, Share of Electrified Railway, Solar Energy, Low-Carbon Growth

\section{Introduction}

In various modes of transportation, the railway is recognized as a type of green and low carbon transport, mainly because it has a large range of technical conditions for the use of electric traction while the other modes of transportation do not possess. In addition, the railway also has unique comparative advantages in the use of new energy and renewable energy, demonstrating in two aspects. One is that the railway traction power (locomotive power) can realize the diversification of the electric energy. Besides the conventional coal and electricity, it can also be widely used the power generated by the use of new energy and renewable energy [1], specifically including energy resources such as biomass energy, wind energy, solar energy, small hydropower, marine energy, geothermal energy, hydrogen energy, and other energy resources; The second is the non-traction energy use (except for locomotive power). Because the number of stations along the rail track is large with relatively concentrated energy, it can also be used in large-scale energy forms provided by new energy and renewable energy, such as electric energy and various kinds of heat energy. Therefore, promoting the utilization of new energy and renewable energy in the railway industry can fully excavate the space of railway energy saving and emission reduction, which is beneficial to promote the lower carbonization of railway operation, and it is possible to take the lead in realizing large scale non-carbonization transport in the local area.

Using new energy and renewable energy sources in railways is very important for building the low-carbon transportation because the effect of energy-saving coming from the railway can produce the outer replacement effect. That is to say, when you use a train instead of a bus or a truck to transport passengers or goods, you can find less energy to be consumed [2]. Therefore, governments can use more trains to replace trucks or buses in transportation as many as possible in order to save energy or better the structure of the energy by 
utilize more new energy and renewable energy.

\section{Potential for Railway Traction to Utilize New Energy and Renewable Energy}

Energy consumption in the railway industry can be divided into two aspects, including traction energy consumption and non-traction energy consumption. The former refers to energy consumption during transport process and the latter refers to the other energy consumption other than the former. Overall speaking, railway traction in most countries in the world accounts for over $50 \%$ of the total railway energy consumption. Therefore, the key to the transport of low carbon and non-carbonization is on the traction energy of the railway locomotive.

The energy use of traction includes three types of fuel energy which are coal electricity, diesel and coal respectively. As the steam locomotive has withdrawn from the historical stage, the main fuel energy is electricity (mainly coal electricity) and diesel. The potential development space in railway industry can be measured by the degree that coal electricity and diesel are replaced by new energy and renewable energy.

\subsection{Improved Space for Railway Power Traction Energy Consumption}

It is not the ultimate goal to improve the electrification rate of the rail line and the proportion of electric locomotives in all locomotives from low carbon and non-carbonization, but from the use of coal and electricity to the use of new energy and renewable energy. But the first critical step is to improve the electrification rate so as to provide technical conditions for the use of new and renewable energy sources. Thus, it can be concluded that the growth trend of the electrification rate is one of the most important potential factors to determine the use of new and renewable energy. As described in table 1, among the major railway countries in the world, five of them have electrification rate above $50 \%$, the highest one is Japan and the subsequent ones are Germany, China, France and Russia. However, in terms of electrified railway mileage, China has more than $6.5 \times 10^{4} \mathrm{~km}$, ranking the first in the worldwide and far ahead of other countries.

In recent years, due to the fast development of high speed railway, the electrification rate of China's railway has been promoted rapidly. The highest contribution to the electrification rate of high speed railway amounts to $61 \%$, with an average of $39.2 \%$ per year. At the end of 2015 , the railway electrification rate exceeded $60 \%$ (see Table 2 ) and was in a leading position in the world. Based on the recent years' speed of development, the railway electrification rate has exceeded $70 \%$ [3], ranking the first in the major railway countries. Therefore, in the field of traction electricity consumption, China has a greater potentiality in new and renewable energy use compared to other countries.

Table 1. Major railway countries indicator comparison.

\begin{tabular}{|c|c|c|c|c|c|c|c|}
\hline \multirow{2}{*}{ Country } & \multirow{2}{*}{$\begin{array}{l}\text { Operation } \\
\text { Mileage/km }\end{array}$} & \multirow{2}{*}{$\begin{array}{l}\text { Electrification } \\
\text { Mileage/km }\end{array}$} & \multirow{2}{*}{ Electrification rate, $\%$} & \multicolumn{4}{|c|}{ Locomotive procession } \\
\hline & & & & Diesel loco & Electrified loco & Steam loco & Total \\
\hline China & 111821 & 65217 & 58.32 & 9485 & 11596 & 15 & 21096 \\
\hline U.S.A & 228218 & & 0.00 & 24047 & & & 24047 \\
\hline Russia & 85248 & 43306 & 50.80 & 9544 & 9808 & & 19352 \\
\hline India & 64460 & 19607 & 30.42 & 4963 & 3586 & & 8549 \\
\hline Japan & 20140 & 12391 & 61.52 & 357 & 551 & & 908 \\
\hline Germany & 33446 & 19876 & 59.43 & 2314 & 2912 & & 5226 \\
\hline France & 30013 & 15768 & 52.54 & 2073 & 1182 & & 3255 \\
\hline Canada & 52002 & 129 & 0.25 & 2752 & & & 2752 \\
\hline
\end{tabular}

Note: China's data for 2014; the United States and India's data for 2009; Russia's data from the OSJD 2011 Railway Transport Statistics Bulletin; other countries data from the UIC 2011 International Railway Information Collection.

Table 2. Change of China electrified railway mileage from 2008 to $2015^{1}$.

\begin{tabular}{|c|c|c|c|c|c|c|c|c|}
\hline Project & 2008 & 2009 & 2010 & 2011 & 2012 & 2013 & 2014 & 2015 \\
\hline $\begin{array}{l}\text { Operation } \\
\text { Mileage/km }\end{array}$ & 8.0 & 8.6 & 9.1 & 9.3 & 9.8 & 10.3 & 11.2 & 12.1 \\
\hline $\begin{array}{l}\text { Electrification } \\
\text { Mileage } / \mathrm{km}\end{array}$ & 2.8 & 3.6 & 4.2 & 4.6 & 5.1 & 5.6 & 6.5 & 7.4 \\
\hline Electrification rate, $\%$ & 34.6 & 41.7 & 46.6 & 49.4 & 52.3 & 54.4 & 58.0 & 61.2 \\
\hline $\begin{array}{l}\text { Contribution } \\
\text { rate of } \mathrm{HSR}^{2}, \%\end{array}$ & 27.2 & 37.5 & 25.9 & 35.5 & 54.5 & 35.0 & 61.0 & 36.7 \\
\hline
\end{tabular}

Note: ${ }^{1}$ Compiled according to Railway Statistics Bulletin from 2008 to 2015 and other relevant data ${ }^{2}$ Contribution rate of HSR $=$ Incremental operating mileage of high speed railway/Incremental electrification mileage of railways.

Other countries, such as the European Union countries, including France, Britain, and Germany, etc., are planning to further develop electrified railways. The EU strongly encourages the member countries to develop high-speed railway, and plans to build the European high-speed railway with a total length of $1.5 \times 10^{4} \mathrm{~km}$ by 2020 . The British 
government has promised to invest 38 billion pounds to improve the railway network, which is mainly to speed up and build high speed railway. In July 2017, the British Parliament approved the construction of a 550 kilometer high-speed rail Connecting cities such as London, Bermingham, Mann, Chester and Liz. The rate of railway electrification will be improved quickly if the United States can achieve its massive high-speed railway program. Australia announced the feasibility study of high speed railway in 2013, planning to build a full length of $1748 \mathrm{~km}$ with a designed speed of not less than $300 \mathrm{~km}$ high-speed railway on the east coast. The project will cost $\$ 114$ billion. According to the report from Czech News Agency in February 24, 2016, Czech's Prime Minister Sobotka announced on his twitter that he and Stanislaw Tillich, the governor of Isaacson, Germany, had agreed to support the high speed railway construction between Prague and Dresden. It can be said that, from the global point of view, the development of high speed railway is in the ascendant. According to the data from the Union of International Railway, the high-speed rail under construction in the world is $15,790 \mathrm{~km}$, and the planned high-speed track is $35,061 \mathrm{~km}$. A recent study by the Boston consultancy group, a US consultancy, predicted that the global high-speed rail market was worth about $\$ 133$ billion in 2019 , higher than the value of $\$ 112$ billion in 2014. It can be seen that the development space of electric traction is considerably large, which creates a solid technical platform for the large-scale application of new and renewable energy.

\subsection{Improvement for Railway Internal Combustion and Traction Energy Consumption}

Another major energy source of traction energy consumption is to fuel oil. In countries with low electrification rate, the proportion of fuel oil in total energy consumption of traction is higher than that of electricity. For example, railways in the U.S., all of them are driven by internal combustion engine vehicles, and all of them are fuel consumption. In countries with high rate of electrification, oil accounts for half of total energy consumption. As a result, using new energy to replace oil is a significant way to achieve low carbonization, which mainly depends on the proportion that biodiesel and liquefied natural gas in replacement of oil. Britain and Canada have tested the technology of mixing combustion materials with bio-diesel oil for locomotives [4]. Russia has been successfully developed and tested the first internal combustion engine locomotive fueled completely by liquefied natural gas in the world. It has been manufactured and prepared for modification and batch production [5].

Another alternative to internal combustion traction is the use of fuel cell. Some railway manufacturers and research institutions, such as Bombardier, European and Japan Railway Research Institute, are studying the feasibility of applying fuel cells to railways. The Japanese Railway Comprehensive Technology Research Institute has successfully developed a hybrid fuel cell locomotive. The East Japan Company has tested the locomotive. Every time a hydrogen fuel is added, the locomotive can run $80 \mathrm{~km}$. In addition to using hydrogen fuel cell tests, the Japan Railway Comprehensive Technology Research Institute is also preparing for feasibility studies of fuel cells using ether, boron and other elements [6].

The new methods of using energy and renewable in railway traction is to directly install equipments on the cars or locomotives of trains. For an example, India installed 16 solar panels on the top of six carriages on trains, mainly for headlights, fans and energy storage systems, which can support 72 hours of electricity. And another example is that Australia launches the world's first fully solar-powered train [7].

However, for the current development trend, there is still a long way to go for the aim of replacing oil and gas with large-scale use of new energy and renewable energy.

\section{Potential for Railways Non-Traction to Utilize New and Renewable Energy}

\subsection{The Application of New and Renewable Energy in the Non-Traction Field}

The use of new and renewable energy in the railway industry first appeared in the non-traction field, from the initial use of solar energy, to the later expansion to the ground source heat pump, to the current air source heat pump (including carbon dioxide air source heat pump), the scale of popularization and utilization is becoming larger and larger, and the coverage is becoming more and more wide. Railway stations, maintenance shops, office buildings and staff apartments gradually use new and renewable sources of energy instead of coal and oil boilers. The problems of heating and air conditioner cooling in office buildings and production workshops have been solved, and better economic and environmental effects have been achieved.

Materials of new and renewable energy have been used in railway construction. Greenrail, an Italian startup, uses waste materials to make sleepers and integrate solar energy systems to power grids and railway stations. In the past, sleepers were made of wood, but in recent years, different materials have been used. Greenrail sleepers are made of rubber from scrap tires and recycled plastics from cities. The shell is coated with an elastic layer, which can reduce the settlement pressure of rails, reduce the maintenance cost by 2-2.5 times, and reduce the replacement times of sleepers. It is estimated that 35 metric tons of scrap materials can be saved per kilometer of rails.

In recent years, some large-scale high-speed railway stations and the reconstruction and expansion of the hybrid stations (EMU and existing trains) have made remarkable achievements in the use of new and renewable energy, such as the Beijing South Railway Station, Shanghai Hongqiao Railway Station and Qingdao Station [7]. These stations actively use solar photovoltaic systems to provide electricity, and many new high-speed railway stations have also widely used new and renewable energy. At the same time, in some cities, the unintegrated heating stations, workshops and office buildings, as well as the production and living energy along 
the remote railway are all accelerating the promotion of new energy and renewable energy utilization technology.

Compared with other modes of transportation, railways have more stations along the lines, and have a larger scale and more concentrated use of energy, creating conditions for the utilization of new and renewable energy. Other modes of transport are basically point to point transportation, and the infrastructure for transport services is small and dispersed. Therefore, energy consumption is relatively dispersed. For example, civil aviation only has airport station with a limited number, there are only more than 20,000 airports in the world. At present, there are no statistics on railway stations all over the world, but it is certain that the number of railway stations in different countries is considerably larger compared with that of airports. For example, the U.K. has 2,500 railway stations, but its number of airports is only 462 in 2013. There are only more than 200 civil airports in China in 2014, and according to the statistics in 2014, there are more than 6,600 stations on National Railways alone [8]. As for waterborne transport, only some of the buildings on the wharf will generate certain energy consumption, and the number and scale of them is limited. Besides, civil aviation and water transport along the way are almost without site and maintenance facilities. Although there are bus stops and highway service areas in highway transportation, they cannot be compared with railways in terms of their scale and quantity. In addition, there are also train depot, locomotive depot, public works section, electrical section, vehicle depot, power supply section, passenger transport section, public works machinery section and communication section in railway. The number of railways in China is around 600. If the energy consumption of these units is gradually replaced by new energy and renewable energy, the zero consumption of coal can be completely realized in the future, so that the coal can be completely withdrawn from the non-traction field. At present, the annual consumption of raw coal in the national railway is above $400 \times 10^{4} \mathrm{t}$.

In addition to energy use in railway building, equipment energy use along the railway is also an important component of non-traction energy consumption, and the application of new and renewable energy in this field is also relatively early. For example, from year 1993 to 1994, the Hainan railway electrical service section applied the solar power supply technology to two newly built projects of the signal narrow pulse track circuit and the communication wireless dispatching, which proved that the equipment is safe, stable, reliable, and no equipment failures occurred [9]. In addition, solar energy is also used in turnout system and communication system. The automatic lubrication system of railway switch machine based on solar energy can combine solar energy application technology with high-speed railway equipment maintenance technology [10]. There were $351 \mathrm{~kW}$ unattended photovoltaic power communication stations have been designed and installed along the Qinghai Tibet railway, which has solved communication power problem of railway construction [11] and so on. In June 30th, 2016, China's first railway photovoltaic power demonstration project was successfully connected to the grid of Sha Liang logistics park in Huhehaote Railway Administrative Bureau in Inner Mongolia [12]. Overall, these applications are mostly scattered, and their scale and impact are much smaller than those in railway construction.

\subsection{The Economic Benefit Analysis of New Energy and Renewable Energy Application in the Non-Traction Field}

It can be provided a brief economic benefit analysis for the application of new energy and renewable energy in the non-traction field.

(1) Reduce labor costs. Taking heating as an example, traditional coal-fired boilers need boiler workers, and requiring at least 2 to 3 people, and at most 6 to 7 people. From the perspective of full cost, the current per capita cost is about 100 thousand yuan per year. If new energy and renewable energy are used for heating, there is no need for personnel to be on duty, and a large labor cost can be saved.

(2) Reduce the cost of coal transportation. Whether coal is produced locally or dispatched, it will result in transportation cost. The farther away, the higher the cost will be. If new energy and renewable energy could be applied, no transportation costs are needed.

(3) There is no need to buy coal and fuel, which greatly saves costs. This main cost can save at least hundreds of thousands, and at most millions. With the use of new and renewable energy, the cost of raw materials can be reduced to zero because these energies are inexhaustible and free of charge.

Undoubtedly these new projects require investment costs, so it is also necessary to consider the cost of investment besides measuring the economic benefits of new and renewable energy projects. According to the output characteristics of such projects, there are two main indicators for comprehensive measurement of economic benefits: first is the rate of return on investment, and the second is the investment recovery period. The investment revenue is actually equivalent to the heating cost of the replaced energy consuming equipment. Taking the solar energy replacing the coal-fired boiler as an example, the income of the solar energy project is equal to the total cost arising from the heating process of the coal-fired boiler, including labor cost, coal purchase, and transportation fees. The rate of return on investment is the ratio of project income to investment. The higher the rate of return on investment, the better the economic benefits of investment projects. The calculation of the investment recovery period is contrary to the rate of return on investment. The investment recovery period is the ratio between the investment and the yield of the project. The shorter the investment recovery period, the better the investment returns. Conversely, the opposite is true.

According to the analysis of the investment projects of new and renewable energy technology transformation for national railways since 2006, the following indexes are obtained: the average investment efficiency of the ground source heat pump 
project is $22.3 \%$; the longest recovery period of the project is 10.3 years, while the shortest is 3 years, and the average is about 5 years. The air source heat pump project investment efficiency is the same as high as $53.6 \%$, most of them are over $30 \%$, with an average of $32.8 \%$, with the longest investment recovery period of 9.8 years, the shortest is 1.87 years, the average is 4 years. The average return on investment of solar projects reaches $38.5 \%$, some of the projects' rate of return on investment can be as high as $90.9 \%$, and the lowest is $18.2 \%$. The shortest investment recovery period is about 1 year, the longest is 7 years or so, averaging about 3.5 years.

Compared to the social average level of other investment projects (see Table 3), it is easy to find out that the economic benefits of railway application of new and renewable energy are better.

Table 3. Comparison of rate of return on investment for major industries.

\begin{tabular}{llll}
\hline Investment area & Rate of return on investment, \% & Investment area & Rate of return on investment, \% \\
\hline Industrial & 10 & Bank savings & 1.5 \\
Real Estate & 7 & Shops and Office buildings & 10 \\
Shares & 5.7 & Life insurance & 7 \\
\hline
\end{tabular}

Source: Compiled according to "China Business Journal", "Newsweek" and "Jiangnan Times" and other newspapers and materials.

The use of new and renewable energy abroad in railways is mainly reflected in solar power generation, among which Germany, the United States and Japan are typical representatives. Deutsche Bahn Company adopted renewable energy on New Berlin terminal building, and high-efficient solar photovoltaic equipment has been installed. The rated power of the entire solar power generation equipment is $189 \mathrm{~kW} \pm 10 \%$. After operation, from the end of June 2002 to the beginning of August, the device transmitted $2.2 \times 10^{4} \mathrm{kWh}$ to the public power grid. The solar photovoltaic system is installed at the junction of Stillwell Avenue subway station and station building in New York, USA. The total power amounts to around $210 \mathrm{~kW}_{\mathrm{p}}$, producing about $250,000 \mathrm{kWh}$ power per year, which can meet the $15 \%$ of annual demand of the station. Under the sunny weather circumstances, the PV system can generate enough electricity to supply $65 \%$ of the electricity demand of the station. Nagoya railway has a solar water heater at the vehicle inspection field in Mougi, Inuyama, and Toyoake. It provides hot water for washing vehicles and has good effect on energy saving and environmental protection.

\section{Applied Direction of New Energy and Renewable Energy in China's Railway Industry}

From the above, it can be seen that the structural optimization of traction energy consumption depends mainly on the continuous improvement of electrification rate, the structural optimization of non-traction energy consumption mainly relies on the popularization and application of new and renewable energy. In recent years, due to the rapid development of high-speed railway and the acceleration of electrified transformation of existing lines, the electrification rate has been quickened, and the structure of traction energy consumption has been greatly improved. The proportion of electricity consumption of total energy consumption has overpassed the fuel consumption, forming the electricity dominant energy consumption structure. Comparatively speaking, the structure of non-traction energy consumption has slowly improved, and coal still occupies an absolutely high proportion. As China's railway non-traction energy consumption accounts for about half of the total railway energy consumption, improving non-traction energy consumption structure has a long way to go, and accelerating the pace of utilization of new and renewable energy has become an important part of energy conservation at present and in the future.

\subsection{Development Direction of Applications in Non-Traction Field}

From the types of new energy and renewable energy currently applied in China's railways, it mainly includes solar energy, ground source heat pumps, and air source heat pumps (including carbon dioxide heat pumps), and the popularization rate of solar energy projects is slightly higher. These projects have their own advantages and disadvantages, and also have different adaptation conditions. In actual use, solar energy has been used in conjunction with ground source heat pump or air source heat pump. Through this combination, their advantages can be brought into full play, effectively making up for the shortcomings of both sides. The combination can have better heating effect and meet the needs of hot water supply under different seasons and different climatic conditions. For example, the combination of air source heat pump and high-power solar water heating system can make full use of solar energy to make heat. In cloudy days and at night, when the solar energy fails to provide heat, the air source heat pump will start to generate hot water in time, thus greatly reducing the consumption of electricity and satisfying the demand.

If a single project is to be chosen in the future, it is necessary to make a careful comparison of various factors and select the best energy projects suitable for the regional characteristics. Generally, the carbon dioxide air source heat pump project is one of the key points for future development. Its advantage is that it is not constrained by climatic conditions. It is suitable for both southern and northern regions, especially working in extremely cold weather. Relatively speaking, it has a broader potential market.

\subsection{Development Direction of Application in Traction Field}

For the sake of transport safety, the structural optimization 
of energy consumption in the traction field deserves more attention. In fact, from the requirement of establishing low-carbon railway, the optimization of energy consumption structure in traction field is more important and crucial than the non-traction area, which occupies a major share. The best way to optimize is to make full use of new energy and renewable energy. The following options are available:

\subsubsection{Bundled Power Supply Mode}

The power supply system adopts dual operation mode that is to connect with local power department. When the solar power system supplies extra electricity, the department can supply the extra for urban power supply. If the local weather is rainy for a long time, the power supply department can provide electricity for the railway system, thus ensuring the safe power supply of the train power system [13]. However, because the power supply is not near the railway line, the long-distance transmission will cause some electrical loss. In addition, the improvement of power supply structure is constrained by the improvement of power supply in the whole society, therefore the utilization of new energy and renewable energy will be relatively small.

In order to improve the shortcomings of this model, the design scheme of the integration of solar photovoltaic power generation system and electrified railway can be considered. Taking 16 meters length as a construction unit and 5 meters length as an interval, the installed capacity of $1-\mathrm{km}$ electrified railway is about $2,300 \mathrm{~kW}$. When the electrified railway section is heading north-south, the solar photovoltaic modules less than 1.8 meters can be installed on both sides of the railway section. To some extent, it can also serve as a sound insulation wall [14]. The advantage of this method is that it can make full use of new and renewable energy in some areas along the railway line, and will not generate electricity loss.

\subsubsection{Hybrid Power Supply with Other Energy Mode}

In some areas where there is no cooperation with the local power supply department, another railway power supply scheme can also be adopted. That is to increase the diesel generator as an emergency power supply on the basis of making full use of the abundant solar and wind energy resources along the line [15].

\section{Policy Support for Railway Application of New and Renewable Energy}

Although railway applications of new and renewable energy have made some achievements, from the perspective of future development, further application needs strong support from relevant policies. From the current situation, the policy of encouraging the development of new and renewable energy has formed primary system. At the national level, China formulated the strategic plan for the development of new energy and renewable energy from 1996 to 2010, and formulated the renewable energy law in 2005. China's railway industry has started to research, develop and popularize new and renewable energy technologies for a long time, and has insisted on the promotion and application of new and renewable energy as a long-term strategic objective for energy conservation and emission reduction in the industry. It has been well reflected from the energy saving technology policy and long-term strategic plan. For example, the railway energy saving technology policy promulgated in September 1999 clearly put forward vigorously developing solar energy utilization, selecting various solar collectors according to local conditions, promoting the use of high efficiency and low-cost medium and small photovoltaic power generation systems; as the fuel acquisition is difficult along the railway lines, people working and living there should actively promote biomass energy conversion technology, acquire large quantities of organic waste water and objects and utilize biogas technology to get clean and convenient high-quality energy; actively develop and utilize wind energy in areas where wind power is abundant, and build a power supply system that combines wind power generation and diesel power generation with solar photovoltaic power generation; fully develop geothermal energy for heating, cooling and other purposes. In March 2007, the former Ministry of Railways promulgated the strategy plan of railway " $11^{\text {th }}$ Five-Year" energy conservation and comprehensive utilization of resources, requiring railway stations and other offices to promote new and renewable energy such as solar energy, wind energy, geothermal energy and other new energy for heating and cooling of building, and for workers and passengers to supply hot water. In March 2012, the former Ministry of Railways promulgated the " $12^{\text {th }}$ Five-Year " railway energy saving strategy plan, and further proposed that every unit should promote the application of new and renewable energy. The administrative organizations should actively promote new and renewable energy such as solar energy and geothermal energy in appropriate areas according to the principle of adjusting measures to local conditions and complementing different types of energy.

In the future, policies still need to be improved in some areas: first, the energy cooperation policy between the power department and the railway department, which mainly involves the cooperation of new and renewable energy in power generation, distribution and transmission. Second is the necessary financial support policy. Generally speaking, the use of coal and electricity by railways is more economical than photovoltaic power generation and wind power generation. However, considering the environmental protection and low-carbon perspective, people should use the latter as far as possible, which requires subsidies from the financial sector. The third is to introduce some incentive policies for scientific research. At present, China's scientific research departments are more concerned about the speed of locomotives, such as speed of $600-\mathrm{km}$ technology, while ignoring the development of some new energy locomotives. This requires some policies to guide some research forces focusing on air powered locomotives, nuclear powered locomotives and so on. Forth, the development policy of new and renewable energy industry needs further improvement, attracting the league of railways and other industries, to form a community, develop together, 
and achieve effective abutment between supply and demand.

\section{Conclusion}

The application of new renewable energy in the railway industry has broad prospects for development and is of great significance for the development of low-carbon railways. The rapid development of the global railway market is actually providing a huge demand market for the development of new energy and renewable energy, which is a rare opportunity for both. With the help of new and renewable energy, railways may become the pioneer in the field of low-carbon and non-carbonization in various industries, and the green environmental impact of railways will be more obvious. Whether this potential can be fully excavated, we need further improvement of relevant policies.

\section{References}

[1] Mu Xianzhong, Liu Bingyi. Research on development and industrialization of new energy and renewable energy [M]. Beijing: Petroleum Industry Press, 2009.

[2] Zhou Xinjun. Research on evaluation system of effect of energy saving and environmental protection in railway [J]. Journal of Railway Engineering Society, 2012 (1): 94-99.

[3] China Railway Corporation.2017Annual Statistical Bulletin [R]. http://www.china-railway.com.cn/cpyfw/tjxx/201803/t201803 28_70388.html.

[4] Su Ming. Canadian Pacific Railway Diesel tested how biodiesel to be used in Locomotives in cold climates [J]. Foreign Diesel Locomotive, 2010 (6): 48.

[5] Wang Yue. New measures have been used by Russian Railway Limited company to save diesel oil [J]. Foreign Diesel Locomotive, 2009 (2): 37-38.
[6] Shen Xilai. New fuel for rolling stock -- fuel cell [J]. Traffic \& Transportation, 200, 25 (4): 8.

[7] Li Kangyan. Discussion on design of solar photovoltaic power generation system in Beijing South Railway Station [J]. Building Electricity, 2008 (11): 8-17.

[8] China's National Bureau of Statistics. China Statistical Yearbook 2017 [M]. China Statistics Press, 2017.

[9] Yao Zhoucai. Elementary analysis on Application of solar power in Hainan railway [J]. Mining and Metallurgy in Hainan, 1999 (4): 39-40.

[10] Ruan Xiaofei, Wen Weigang, Fu Maojin. Study on dynamic lubrication system used in railway turnout switch machine on the base of solar energy [J]. Chinese Railways, 2012 (11): 70-72.

[11] Zhao Shu, Cheng Fuyuan, Cao Minglei. Application of solar energy in Qinghai Tibet Railway Construction [J]. Solar Energy, 2003 (5): 38-39.

[12] Jin Quan. The first national railway demonstration project of photovoltaic power generation was connected to the grid $[\mathrm{N}]$. http://inews.nmgnews.com.cn/system/2016/06/30/012049218. shtml.

[13] Wang Zhiru, Meng Yahui, Shen Run, el. Research on New railway transportation Model based on solar power generation [J]. China Venture Capital, 2013 (30): 89-91.

[14] Zhu Yeshu. Discussion on integration of solar photovoltaic power generation system and electrified railway [J]. China High-Tech Enterprises, 2015 (12): 82-83.

[15] Xu Zhenzhe. Application and vision of solar energy and wind power generation in Jiaxi Railway [J]. Gansu Science and Technology, 2008, 24 (14): 82-84, 164. 